Ian M. Kenway:

\title{
Controversy and Charity: The Disembodiment of Religion in Cyberspace
}

\begin{abstract}
:
The paper explores the limitations and distortions of religious discussion on the Internet within the wider context of those ethical challenges posed by controversy and debate in cyberspace where "language that is no longer checked and verified by physical reality loses its very grounding". In particular, it attempts to establish a series of critical connections between the emergence of polemical forms of 'feuilletonism' in the area of religious comment and the characteristic weightlessness of language which has become detached from the body, despite the latter's extension and intensification in the concrete social realisations found in specific faith communities.
\end{abstract}

\section{Agenda}

Introduction

Narrow Bandwidth/Flattened World

Courtesy, Civility and Conviviality

\section{Author:}

Dr. Ian M. Kenway:

- Cardiff School of Religious and Theological Studies, Cardiff University, Humanities Building, Colum Drive, Cardiff, CF10 3EU, Wales, UK, and Cardiff School of Computer Science, Cardiff University, 5 The Parade, Cardiff, CF24 3AA, Wales, UK.

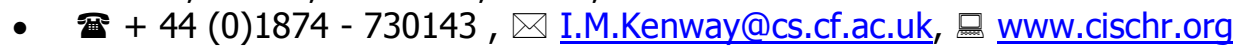

Relevant publications:

Could Do Better? - Hegemony and Freedom in Cyberspace. In: Ethics, Law and Society, Vol. III, ed. by Jennifer Gunning and Søren Holm, Cardiff: Ashgate, 2007, pp. 237-240.

Only Connect - Broadboard Provision and Social Inclusion. In: Ethics, Law and Society, Vol. I, ed. by Jennifer Gunning and Søren Holm, Cardiff: Ashgate, 2005, pp. 173-186.

Internet Governance. In: Ethics, Law and Society, Vol. I, ed. by Jennifer Gunning and Søren Holm, Cardiff: Ashgate, 2005, pp. 269-272.

Blessing or Curse? Autism and the Rise of the Internet. In: Journal of Religion, Disability \& Health, ed. by William C. Gaventa, (published by Haworth Press Inc.); (forthcoming). 


\section{Introduction}

It is not surprising that the Internet offers a useful platform or medium for both serious and more trivial discussion about religious belief and belonging. In recent years this has taken place increasing on weblogs which may or may not have been established by religious institutions, organisations or groups. Like those dedicated to sport and politics (to take two obvious examples) these frequently engender passions and psychodynamic energies which move significantly beyond the mere description of specific belief systems or the practices of particular faith communities.

Clearly the Internet provides (as it does, respectively, for almost every area of human knowledge) a much appreciated and used gateway for accessing and retrieving significant theological resources. However, it also offers at the same time a powerfully seductive arena in which religious beliefs do not merely get presented and convivially discussed but also baldly and repeatedly asserted in ways which can be genuinely hurtful and sometimes purposefully destructive.

According to Douglas Cowan "Taken together, the Internet and the World Wide Web constitute a more efficient technological platform for a contest that has been ongoing in the real world for millennia: the control, manipulation, and, most significantly, replication of symbolic resources". ${ }^{1}$ However such a contest does not automatically lead to the kind of objectified knowledge which Gernot Böhme described nearly twenty years earlier as "the highly differentiated stock of intellectually appropriated nature and society which may also be seen to constitute the cultural resource of a society" ${ }^{\prime 2}$.

In one sense, there is nothing new here. Religious debate in the past has rarely been anodyne as witnessed by the phrase odium theologicum. However, the virtual world offered by the Internet offers greater scope for odium theologicum than perhaps hitherto because of its theoretical ability to allow the opinions of anyone to be published (leaving aside the spectre or, indeed, the actual practice of censorship) without reference to tradition, canon or other relevant authority - past or present.

While comments on sport and politics populate the 'blogosphere' in fairly predictable ways, religious debate qua controversy is perhaps less happily served by the practice of 'blogging'. In particular the latter frequently fails to do justice to the way in which most religions seek to maintain and indeed foster the fundamental connections between enlightenment and civility, transcendence and genuine 'humanness'. Such connections are fragile at the best of times. However, the Internet, or more specifically the blogosphere, puts these connections at greater risk by limiting the ways in which we can understand and essay the truthfulness of specific claims.

Unfortunately, although there is now a significant and growing body of research dealing with religion on the Internet, very little of it at present deals specifically with the phenomenon of blogging. This relative dearth of interest may reflect the fact that blogging about religion, either in terms of beliefs or practices, frequently evades categorisation as either religion online or online religion, a distinction first made by Christopher Helland (2000) and subsequently developed by others. Most internet researchers tend to be interested in either how religious institutions, organisations or groups use the internet to promote their existence, tenets or practices or how the internet provides a suitable space for the develop new modalities of religious or spiritual expression. According to Morten Højsgaard, "The cyber-religious field, moreover, is characterized by such features as role-playing, identity constructions, cultural adaptability, fascination with technology, and a sarcastic approach to conformist religiosity. ${ }^{\prime \prime 3}$

However much blogging about religion takes place on websites which are avowedly secular in intent and orientation; many of them indeed are promoted and maintained by those with a significantly continuing stake in traditional media (print and broadcasting). This allows not only the participation those either broadly apathetic or disaffected from religion, but also those who do not have a particularly strong interest in the internet itself.

\footnotetext{
${ }^{1}$ Dawson and Cowan 2004, p. 267.

2 Böhme 1986, p. 21.
}

${ }^{3}$ Højsgaard and Warburg 2005, p. 62. 
The phenomenal rise of blogging on the internet, assisted by easily implemented software, should not be underestimated; certainly it represents a significant development from the early days of web publishing which, to a large extent, was severely limited to the provision and access of discrete information. Blogging is, for many individuals, the main form in which the Internet 'comes to life', offering the possibility of participation rather than mere perusal.

Perhaps not surprisingly controversy and blogging feed off each other. Increasingly searches in cyberspace demonstrate the way in which subjects that generate intense controversy, hot topics, are to be found predominantly (at least in terms of volume) on blog pages rather than 'official pages' or pages of 'public record'. This is certainly the case when it comes to religious controversy. The ongoing dispute concerning the consecration of Gene Robinson, an openly gay priest, as Episcopal Bishop of New Hampshire in 2003 for example, generated on 23 June 2008 290,000 hits on Google of which 226,000 relate to blog pages (78\%). The controversy concerning the publication of cartoons depicting the prophet Mohammed by Jyllands-Posten in 2005 generated 173,000 hits on Google on the same date of which 135,00 relate to blog pages (again 78\%). Jerry Springer the Opera, which attracted attention for its alleged blasphemous portrayal of Jesus amongst certain Christian groups in the U.K., generated 127,000 hits on the same date of which 72,400 relate to blog pages (57\%). Finally the forced closure of Gurpreet Kaur Bhatti's play Behzti (Betrayal) at the Birmingham Repertory Theatre in 2005, which among other thing depicted rape in a Sikh temple, generated 4,960 hits on Google, again on 23 June 2008, of which 1,910 relate to blog pages (39\%). Clearly these figures need to be interpreted with a severe methodological 'health warning', not least with regard to the assumptive biases of search engine algorithms and the dominance of English language in metadata. Nonetheless the trend is significant and revealing.

\section{Narrow Bandwidth/Flattened World}

Unfortunately the slogan that the Internet makes 'geography history' is seriously at odds, possibly irreconcilably, with the idea that religious beliefs are irrefragably rooted to events in particular times and places, even when their espoused doctrines and attendant worshipping practices are deemed of universal significance and benefit. While hypertextuality and iconic navigation through cyberspace initially suggest a vastly expanded world of richness, complexity and nuance, such conventions more often than not belie a seriously 'flattened' world, effectively limited to two senses.

According to Dan Thu Nguyen and Jon Alexander:

"Language that is no longer checked and verified by physical reality loses its very grounding. Eventually it may cease to maintain its raison d'être as a tool for human communication. Without the materiality of lived existence how can one sustain responsibility for one's words, written or oral? How can people say what they mean and mean what they say? In short, to what does language refer?" ${ }^{4}$

Such a world soon becomes 'feuilletonistic' in character as described by Hermann Hesse in The Glass Bead Game. ${ }^{5}$ Indeed the latter writes of a cultural landscape which adventitiously envisages the Internet qua blogosphere.
"...in the course of the aforementioned Age of the Feuilleton, men came to enjoy an incredi- ble degree of intellectual freedom, more than they could stand. For while they had over- thrown the tutelage of the Church completely, and that of the State partially, they had not succeeded in formulating an authentic law they could respect, a genuinely new authority and legitimacy. Ziegenhalss recounts some truly astonishing examples of the intellect's debasement, venality, and self-betrayal during that period." 6

Cultural landscapes cannot be divorced from their epistemological presuppositions and epistemic practices, however obscure or deeply embedded, and these in turn are necessarily earthed, though not unambiguously, in how we understand and expressly give meaning to our bodies. According to Maurice Merleau-Ponty, "we must avoid saying

\footnotetext{
${ }^{4}$ Nguyen and Alexander 1996, p. 104.

${ }^{5}$ Hesse 1972, p. 22.

${ }^{6}$ Hesse 1972 , pp. 22-23.
} 
that our body is in time, or in space. It inhabits space and time ${ }^{\prime \prime}$. More specifically he observes:

\begin{abstract}
"The body is our general medium for having a world. Sometimes it is restricted to the actions for the conservation of life, and accordingly it posits around us a biological world; at other times, elaborating upon these primary actions and moving from their literal to a figurative meaning, it manifests through them a care of new significance: this is true of motor habits such as dancing. Sometimes, finally, the meaning aimed at cannot be achieved by the body's natural means; it must then build itself an instrument, and it projects thereby around itself a cultural world. ${ }^{18}$
\end{abstract}

The role of the imagination in epistemology, rooted in our bodily or sensuous existence alone allows for a genuinely understanding of the world, morally as well as socially and culturally. This has been explored by both theologians such as John Henry Newman, whose exploration of 'natural inference' and the 'illative sense' in An Essay in Aid of $A$ Grammar of Assent ${ }^{9}$ can be understood as an 'objective critical psychologism', and by philosophers such as Michael Polanyi whose discussion of 'tacit knowledge' or 'connoisseurship' is rooted in an understanding of knowledge as a necessarily complex interaction with the world. In Knowing and Being, Polanyi observes:

\begin{abstract}
"We can account for this capacity to know more than we can tell if we believe in the presence of an external reality with which we can establish contact. This I do. I declare myself committed to the belief in an external reality gradually accessible to knowing, and I regard all true understanding as an intimation of such a reality which, being real, may yet reveal itself to our deepened understanding in an indefinite range of unexpected manifestations. $^{110}$
\end{abstract}

\footnotetext{
7 Maurice Merleau-Ponty, 1962, p. 139.

8 Merleau-Ponty 1962, p. 382.

${ }^{9}$ Newman 1979, pp. 230-299.

${ }^{10}$ Polanyi 1969, p. 133.
}

\section{Courtesy, Civility and Conviviality}

Ultimately the limitations and distortions of religious discussion on the Internet are created through the relative privileging of assertoric statements of belief over non-cognitive aspects of religious life and experience such as courtesy, civility and conviviality.

\section{According to George Steiner:}

"Very concretely, the phenomenology of courtesy would organize, that is to say quicken into articulate life, our meeting with the other, with the beloved, with the adversary, with the familiar and the stranger. It would, on a tree of meaning, connect with the only partially perceived encounters between our conscious and unconscious selves to those meetings which take place in the lit spaces of social, political and moral conduct."

"The informing agency is that of tact, of the ways in which we allow ourselves to touch or not to touch, to be touched or not to be touched by the presence of the other... The issue is that of civility (a charged word whose former strength has largely left us) towards the inward savour of things. What means have we to integrate that savour into the fabric of our own identity? ?d1 $^{2}$

'Netiquette' is no substitute for cortesia. What are often missing in the blogosphere and elsewhere on the Net are those social clues which allow meaningful discourse and engagement. It may be, as Brenda Brasher observes, that much online communication exhibits "the free and easy neighborliness that characterizes a great deal of cyberspace conversation is an incredible testament to the human capacity to love one another - even strangers you have never seen and may never meet in your entire life. ${ }^{12}$ Nonetheless much discussion on the Internet, especially on religion, and especially in the blogosphere, has a peculiarly 'autistic' quality to it. According to Damien Atkins, "a lot of autistic symptoms or autistic behaviors are really human behaviors magnified or dimmed

\footnotetext{
${ }^{11}$ Steiner 1989, pp. 147-149.

${ }^{12}$ Brasher 2001, p. 118.
} 
to an extreme, like an oversensitivity or an undersensitivity. ${ }^{13}$

Such distortions of sensitivity are often primed by how traditional media handle controversy. According to Julian Baggini:

"There is something to be said for presenting a debate in terms of the two strongest cases that can be made on either side. But this can also lead to important distortions. This is particularly important in issues of great sensitivity such as 'Behzti'... The problem is that the traditional way of balancing is not just one way that debates are presented, but the formula that is almost invariably followed. The cumulative effect of all these discussions is to present a picture of a society which is dominated by adversarial conflicts and huge gulfs. The moderate middle ground, occupied by the majority, is left unrepresented, and so the striving for balance actually fails to fulfil its primary purpose of reflecting the opinions that are out there. ${ }^{14}$

If traditional media have difficulty in handling controversial issues in a non-adversarial way, then a fortiori the virtuality of the Internet, with its radical foreshortening of distance and time, provides considerable difficulties for the practice of courtesy, civility and conviviality when it comes to vigorous religious debate. The non-physical nature of the on-screen environment encourages at best ambiguity and at worst obfuscation or naivety. In cyberspace there is no obvious way in which truthclaims can be checked out provisionally and practically, let alone juridically or determinatively.

Can on-line communities, not just within the Christian tradition, foster spiritual maturity through friendship qua brotherhood/sisterhood or their contemporary equivalents in the same way as envisaged by, say, Aelred of Rievaulx in his treatises The Mirror of Charity and Spiritual Friendship, in which Cicero's notion of union in friendship is re-imagined as the genuine basis of true spiritual development ${ }^{15}$, or, centuries later, Dietrich Bon-

${ }^{13}$ Atkins 2007.

${ }^{14}$ Baggini 2005.

${ }^{15}$ Squire 1973, p. 106. hoeffer vision of 'community life' in Life Together ${ }^{16}$ in which the Ministries of 'Holding One's Tongue', 'Meekness', 'Listening', 'Helpfulness' and 'Bearing' are seen as at least as important as the Ministries of Proclaiming and Authority? Questions such as this need to be explored more thoroughly when it comes to understanding the various relationships that have developed between religion and the internet.

When imagination goes hand in hand with courtesy, new forms of understanding neighbourhood and community emerge through our striving for solidarity with those who are progressively distant and different from 'ourselves'. Solidarity is a construct not a given. However, this does not detract in any way from its importance or imperative. Richard Rorty comments, for example:

"We need to realize that a focus imaginarius is none the worse for being an invention rather than (as Kant thought it) a built-in feature of the human mind. The right way to take the slogan "We have obligations to human beings as such" is as a means of reminding ourselves to keep trying to expand our sense of 'us' in the direction set by certain events in the past The right way to construe the slogan is a urging to create a more expansive sense of solidarity than we presently have. The wrong way is to think of it as urging us to recognize such a solidarity, as something that exists antecedently to our recognition of it. ${ }^{\text {id7 }}$

Spiritual knowledge, like all forms of knowledge, must take the form of solidarity, a reaching out to that which is other. However it is a process which can only be realised through and by the body. Indeed no satisfactory account can be given of certain knowledge which does not proceed from a genuinely incarnational model of human rationality in which both imagination and conscience play a role as significant as discursive reason. The personal character of knowledge demands such an epistemology since when we know something for certain - in Wittgenstein's 'animal' sense ${ }^{18}$ - there is an engagement of the whole person - both as a historical and social being. Imagination and con-

\footnotetext{
${ }^{16}$ Bonhoeffer 1972, pp. 69-85.

${ }^{17}$ Rorty 1992, p. 196.

${ }^{18}$ Wittgenstein $1974,47^{c}, 359$.
} 
science root human rationality primordially in time and space. That is why our acts of judgment always find themselves witnessing, without exception, to the bodily nature of our existence - even in the depths of cyberspace.

\section{References}

Atkins, Damien: The Scientist, 2 November 2007

Baggini, Julian: The Problem With Balanced Debates. Online: http://onegoodmove.org/1gm/1gmarchive/ 2005/06/the problem wit.html (retrieved 23 June 2008)

Böhme, Gernot and Stehr, Nico: "The Growing Impact of Scientific Knowledge on Social Relations", In: G. Böhme and Nico Stehr (eds.): The Knowledge Society: The Growing Impact of Scientific Knowledge on Social Relations. Berlin: Springer 1986.

Bonhoeffer, Dietrich: Life Together. SCM, 1972.

Brasher, Brenda E.: Give Me That Online Religion, Jossey-Bass 2001.

Dawson, Lorne L. and Cowan, Douglas E.: Religion Online: Finding Faith on the Internet. London: Routledge and Kegan Paul 2004.

Helland, C.: Online Religion/Religion Online and Virtual Communitas. In: Jeffery $K$. Hadden and Douglas E. Cowan (Eds.), Religion on the Internet: Research Prospects and Promises. New York: JAI Press 2000.

Hesse, Hermann: The Glass Bead Game. Penguin 1972.

Højsgaard, Morten T.: Cyber-religion: on the cutting edge between virtual and real. In: Morten T. Højsgaard and Margit Warburg (eds.): Religion and Cyberspace. London: Routledge and Kegan Paul 2005.

Merleau-Ponty, Maurice: Phenomenology of Perception, London, Routledge 1962.

Newman, John Henry: An Essay in Aid of a Grammar of Assent. Notre Dame, 1979.

Nguyen, Dan Thu and Alexander, Jon: The coming of Cyberspacetime and the End of Polity. In: Rob Shields (ed.): Cultures of Internet - Virtual Spaces, real Histories. SAGE, 1996.

Polanyi, Michael: Knowing and Being. London: Routledge and Kegan Paul 1969.

Rorty, Richard: Contingency, irony and solidarity. Cambridge University Press, 1992.
Squire, Aelred of Rievaulx - A Study, London, SPCK, 1973.

Steiner, George: Real Presences. Faber and Faber, 1989.

Wittgenstein, Ludwig: On Certainty (eds. Anscombe, G.E. and von Wright, G.H.). Oxford: Blackwell 1974. 